\title{
Modified icing system containing mint leaf and citrus peel extracts: effects on quality changes and shelf life of Indian mackerel
}

\author{
P. VIJI ${ }^{1}$, P. K. BINSI ${ }^{2}$, S. VISNUVINAYAGAM ${ }^{2}$, C. N. RAVISHANKAR ${ }^{3}$, G. VENKATESHWARLU ${ }^{4}$ \\ AND T. K. S. GOPAL ${ }^{3}$ \\ ${ }^{1}$ Visakhapatnam Research Centre of Central Institute of Fisheries Technology, OceanView Layout, Pandurangapuram \\ Andhra University, P. O., Visakhapatnam - 530 003, Andhra Pradesh, India \\ ${ }^{2}$ Mumbai Research Centre of Central Institute of Fisheries Technology, Vashi, Navi Mumbai \\ Maharashtra - 400 703, India \\ ${ }^{3}$ Central Institute of Fisheries Technology, Kochi - 629 503, Kerala, India \\ ${ }^{4}$ Indian Council of Agricultural Research, Pusa, New Delhi - 110 012, India \\ e-mail: pankyammaviji@gmail.com
}

\begin{abstract}
The efficacy of ice containing mint (Mentha arvensis) leaf extract $\left(700 \mathrm{mg} \mathrm{l}^{-1}\right)$ and citrus (Citrus aurantium) peel extract (1000 $\left.\mathrm{mg} \mathrm{l}^{-1}\right)$ in retarding the biochemical, microbiological and sensory changes in whole Indian mackerel was assessed. Presence of extracts in ice significantly $(\mathrm{p}<0.05)$ reduced the generation of total volatile base nitrogen (TVB-N), trimethyl amine nitrogen (TMA-N) and free fatty acids (FFA) during storage. Moreover, a marked inhibition of lipid oxidation was also observed in samples stored in ice with extracts, as indicated by its lower peroxide value (PV) and thiobarbituric acid reactive substances (TBARS) compared to that of control. Additionally, icing with extract substantially reduced the count of total viable bacteria, as compared with the samples stored under conventional icing system. According to sensory evaluation, shelf life of Indian mackerel was determined to be 13 days for fishes stored under conventional icing system, 15 days for fishes stored in ice containing citrus peel extract and 17 days for the fishes kept in ice containing mint extract.
\end{abstract}

Keywords: Antioxidant activity, Icing system, Indian mackerel, Plant extracts, Shelf life

\section{Introduction}

Constituents or extracts from plant sources are considered as bio-preservatives and in recent years, researchers have been giving increased attention to the positive role of extracts obtained from plant sources for food applications. The antibacterial and antioxidant activities of extracts obtained from different plant sources against food borne pathogens and food spoilage bacteria are well demonstrated (Shan et al., 2007; Babbar et al., 2011). Mentha species, belonging to the family Laminaceae is a rich source of antioxidants and antibacterial compounds (Moreira et al., 2005; Kannatt et al., 2008). Citrus peel, a major contributor to fruit juice waste is rich in phenolic compounds such as phenolic acids and flavonoids with good antioxidant power (Wang et al., 2008).

Icing and mechanical refrigeration are the most prevalent techniques to control microbial and biochemical spoilage of freshly caught fish during distribution and marketing in tropical countries. However, shelf life of ice stored fish is often limited due to post-mortem autolysis, microbial growth and lipid oxidation. Lipid deterioration is considered to be the major cause of off-flavour development and quality loss of fishes during iced storage, particularly in semi fatty/fatty fishes. Recent studies have shown significant inhibitory effects of ice incorporated with natural antimicrobials and antioxidants on the microbiological and biochemical mechanisms involved in fish spoilage, as compared to conventional icing (Oral et al., 2008; Garcia-Soto et al., 2013; Bensid et al., 2014). These studies demonstrated that storage of fish in ice incorporated with extracts from plant sources retarded the biochemical, sensory and microbiological changes and extended the shelf life compared to control samples.

Indian mackerel (Rastrelliger kanagurta) contributes to a major quantity of pelagic fatty fishes harvested across the Indian coast. Being a semi-fatty fish and good source of marine lipids, the Indian mackerel attracts great attention owing to the positive role of marine lipids in human nutrition (Viji et al., 2015). However, effective and eco-friendly methods for controlling spoilage and improving quality of fresh Indian mackerel are necessary. Shinde et al. (2015) reported positive effects of pomegranate peel and tea leaf extracts on the quality changes of mackerel during chilled storage. In our previous study (Viji et al., 2015), dip treatment in mint 
and citrus peel extract had shown shelf life extension of mackerel stored at $0-2^{\circ} \mathrm{C}$. The present study was aimed to investigate the efficacy of ice incorporated with extracts from mint leaf and citrus peel against that of conventional icing on improving the quality and shelf life of whole Indian mackerel during storage.

\section{Materials and methods}

Mint (Mentha arvensis) and citrus (Citrus aurantium) peels were procured from nearby vegetable market, Vashi, India. Fresh Indian mackerel (weight $180 \pm 20 \mathrm{~g}$; length $15 \pm 2 \mathrm{~cm}$ ) was procured from the fish landing centre, Vashi, Navi Mumbai, India and brought to the laboratory in iced condition within $15 \mathrm{~min}$.

Preparation of extract and estimation of antioxidant activities

Extracts from mint leaf and citrus peel were prepared as described earlier by Viji et al. (2015). Total phenolic content in the extracts was estimated by the method of Singleton and Rossi (1965) and the results were expressed as $\mathrm{mg}$ gallic acid equivalent per g dry wt. of the extract. Total flavonoids of the extracts were determined by the method described by Ordonoz et al. (2006) based on the formation of a flavonoid aluminium complex. The total flavonoid content of the extracts was calculated from the equation derived from the standard curve of quercetin and the results are expressed as mg quercetin equivalent per $\mathrm{g}$ of extract. Ferric reducing antioxidant power (FRAP) assay was done according to the procedure of Benzie and Strain (1996). The standard curve was constructed using iron (II) sulfate solution $(100-1500 \mu \mathrm{m})$ and the results were expressed as $\mu \mathrm{mol} \mathrm{Fe}^{2+}$ per mg of the extract. All the measurements were taken in triplicate and the mean values were calculated.

\section{Preparation of plant extract-ice and storage of fish}

Mint extract solution (700 $\left.\mathrm{mg} \mathrm{l}^{-1}\right)$ and citrus extract solutions $\left(1000 \mathrm{mg} \mathrm{l}^{-1}\right)$ were prepared in $2 \mathrm{ppm}$ chlorinated water. Two litres of each solution were packed in a polyethylene bag and frozen to $0^{\circ} \mathrm{C}$ in a commercial plate freezer. Conventional ice was prepared from $2 \mathrm{ppm}$ chlorinated water. Concentrations of plant extracts were chosen based on the results of the preliminary trials (100 - 1000 mg plant extract $\mathrm{l}^{-1}$ distilled water), where the fishes stored were visually analysed and a concentration which gave the best appearance of fish with less presence of colour of plant extract was chosen. The ice blocks were crushed before use.

The whole mackerel was washed thoroughly in potable water and divided into 3 lots. First lot was stored in conventional ice ( $\mathrm{C}$ ice), the second was stored in ice containing mint extract (ME ice) and the third lot in ice containing citrus extract (CE ice) in individual thermocole boxes in 1:1 fish to ice ratio. The boxes were further stored in a vertical chiller maintained at $0-2^{\circ} \mathrm{C}$. Re-icing was done every day to maintain the ratio of fish to ice as $1: 1$ in each group. Three fishes from each box were sampled at days 1, 4, 7, 10, 13, 15, 17 and 18 and analysed for biochemical, microbiological and sensory qualities. All the analyses were done in triplicate.

Quality assessment

Biochemical analysis

Proximate composition of the raw fish was determined by AOAC (1998) method. pH was determined using a glass electrode digital pH meter (Cyberscan 510, Eutech instruments, Singapore) after making a homogenate of fish muscle in distilled water $(1: 5 \mathrm{w} / \mathrm{v})$. Non-protein nitrogenous (NPN) content of the samples was measured by estimating nitrogen in the TCA extract using Kjedahl distillation method (Alongo et al., 1994). Total volatile base nitrogen (TVB-N) and trimethyl amine (TMA) was estimated by the microdiffusion method (Conway, 1950). Thiobarbituric acid reactive substances (TBARS) (Tarladgis et al., 1960) as well as peroxide value (PV) (Yildiz et al., 2003) of the muscle were measured to assess the oxidative rancidity. Free fatty acid (FFA) value was determined as per AOAC (1989) to assess the hydrolytic rancidity.

\section{Microbiological analyses}

Aerobic plate count (APC) of the samples was analysed according to the method of Ryser and Schuman (2013). Fifty gram of fish muscle was homogenised with $450 \mathrm{ml}$ of phosphate buffer for $2 \mathrm{~min}$. Decimal dilutions were made in phosphate buffer and $1 \mathrm{ml}$ each of three consecutive dilutions were plated on plate count agar (Difco). Plates were incubated at $35 \pm 2^{\circ} \mathrm{C}$ for $48 \pm 2 \mathrm{~h}$ for obtaining total viable count.

\section{Sensory analysis}

Raw and cooked pieces were analysed by a panel of 6 experienced members. A 9 point hedonic scale as described by Amerine et al. (1965) was used to score various characteristics like colour, odour, texture and flavour. The overall acceptability score was determined taking into account the total score obtained for raw and cooked samples. Samples were rejected when the overall acceptability score reached 4.

\section{Statistical analysis}

All the measurements were taken in triplicate and the data were subjected to analysis of variance (ANOVA) using SPSS software version 16. Difference between the mean values of various treatments and storage days was analysed by Duncan's multiple range test using SPSS and the significance was defined at $\mathrm{p}<0.05$. 


\section{Results and discussion}

\section{Total phenolic and flavonoid content}

Yield of mint leaf and citrus peel extracts were $14-15 \%$ and $16-18 \%$, respectively. The analysis revealed significantly higher amount of phytochemicals (phenolics and flavonoids) in mint extract compared to citrus extract (Table 1). The total phenolic contents of citrus peel extracts were much lower than those reported by Ghasemia et al. (2009) (132.2 - $223.2 \mathrm{mg}$ GAE per g dry matter) whereas the polyphenol content of mint extract in our study $\left(127 \pm 8.2 \mathrm{mg} \mathrm{GAE} \mathrm{g}^{-1}\right)$ was comparable to those observed in methanolic extract of M. longifolia $(107.20 \pm 34.2 \mathrm{mg}$ GAE g dry $w^{-1}$ ) by Janifer Raj et al. (2010). Ghasemia et al. (2009) reported the flavonoid content in methanolic extracts of 6 citrus varieties which ranged from $0.3-31.7 \mathrm{mg}$ quercetin equivalent $\mathrm{g} \mathrm{wt}^{-1}$, while Asjad et al. (2013) obtained flavonoid content varying from $0.2-25.7 \mathrm{mg}$ quercetin equivalent $\mathrm{g} \mathrm{wt}^{-1}$ in 6 common citrus varieties of Pakistan. The flavonoid obtained for citrus extract in the present work was much higher than that reported in literature, probably due to the difference in extraction procedure. Phenolic compounds of plants are present in different bound status depending on species and hence, effective processing steps for liberating phenolic compounds from various plants may be different (Jeong et al., 2004). This reason might have accounted for the significant difference in total phenolic and flavonoid content between citrus peel and mint extracts.

\section{Ferric reducing antioxidant power (FRAP) assay}

In this assay, the antioxidant capacity is measured based on the ability to reduce ferric ion to ferrous ion by donating an electron and the results are expressed as $\mu \mathrm{mol}$ $\mathrm{Fe}^{2+} \mathrm{mg}^{-1}$ of the sample. The FRAP of mint extract was significantly $(p<0.05)$ higher than that of citrus extract (Table 1). This might be due to the higher concentration of phenolic and flavonoid compounds present in the same. It has been reported that the reducing power might be due to hydrogen-donating ability and is generally associated with the presence of reductones (Duh, 1998). Stanisavljevic et al. (2012) observed that the FRAP values of extracts of M. longifolia prepared using $70 \%$ ethanol varied from 1.22-2.76 mM FeSo $\mathrm{m}_{4}$ dry $\mathrm{wt}^{-1}$. In the present study, $M$. arvensis extract showed FRAP value of $1340 \pm 34.11$ $\mu \mathrm{m} \mathrm{Fe} \mathrm{Fg}^{2+} \mathrm{mg}^{-1}$ wich was comparable to that of butylated hydroxy toluene (BHT) (1712 \pm 42.76$)$. The data available in literature on the FRAP assay of Citrus spp. and Mentha spp. are scattered and is often difficult to compare because of the differences in the methodologies and in the expression of results.

\section{Proximate composition of mackerel}

Fresh mackerel used in this study showed $74.32 \pm 0.85 \%$ moisture, $21.15 \pm 0.743 \%$ protein, $3.38 \pm 0.29 \%$ fat and $1.06 \pm 0.03 \%$ ash content. The results indicated higher protein content and hence, mackerel is considered to be one of the cheap sources of protein. Fat content indicated a semi fatty nature of mackerel muscle. Comparatively higher moisture content contributes to faster spoilage due to microbial growth (Viji et al., 2015).

$p H$

A significant increase $(\mathrm{p}<0.05)$ in $\mathrm{pH}$ was noticed in all the samples over the storage period (Fig. 1). No significant difference between $\mathrm{pH}$ of different groups was observed till 7 days of storage in ice. However, after 7 days, the samples kept in conventional ice showed significantly higher $(\mathrm{p}<0.05) \mathrm{pH}$ than its counterparts stored in ice containing plant extracts. On days 15 and $17, \mathrm{CE}$ iced group presented significantly higher $(\mathrm{p}<0.05)$ $\mathrm{pH}$ than $\mathrm{ME}$ iced group. $\mathrm{pH}$ of the samples reached 7.12, 7.02 and 7.11 in samples stored under conventional ice, $\mathrm{CE}$ ice and ME ice, on their sensory rejection days i.e., on $15^{\text {th }}, 17^{\text {th }}$ and $18^{\text {th }}$ day, respectively.

Comparison among samples (Fig. 1) indicated that presence of extracts in ice significantly $(p<0.05)$ reduced the $\mathrm{pH}$ value of whole mackerel during extended storage. Similar results have been reported by Quitral et al. (2009)

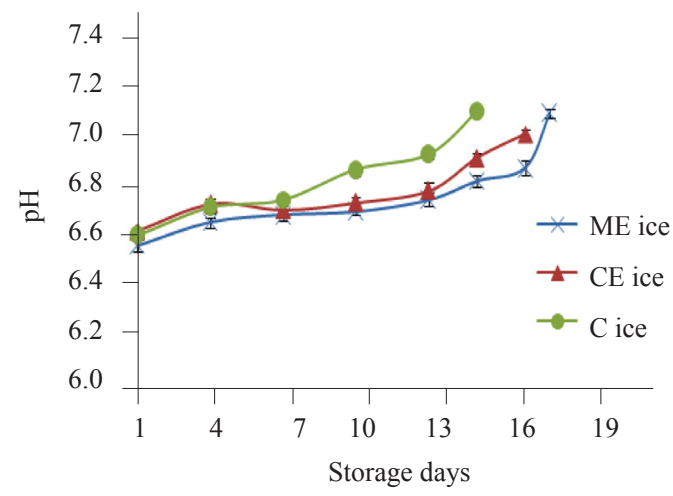

Fig. 1. Effect of different icing systems on the $\mathrm{pH}$ of indian mackerel during storage (Mean $\pm \mathrm{SD}, \mathrm{n}=3$ )

Table 1. Antioxidant activities of the extracts

\begin{tabular}{llll}
\hline Parameter/Source & Mint leaf extract & Citrus peel extract & BHT \\
\hline Total phenolic content $\left(\mathrm{mg}\right.$ gallic acid eq. $\left.\mathrm{g} \mathrm{wt}^{-1}\right)$ & $108^{\mathrm{b}} \pm 6.7$ & $74.8^{\mathrm{a}} \pm 5.3$ & NA \\
Total flavonoid content $\left(\mathrm{mg}^{\mathrm{a}}\right.$ quercetin eq. $\left.\mathrm{g} \mathrm{wt}^{-1}\right)$ & $91.14^{\mathrm{b}} \pm 6.32$ & $66.94^{\mathrm{a}} \pm 5.43$ & NA \\
FRAP $\left(\mu \mathrm{mol} \mathrm{Fe}^{2+} \mathrm{mg}^{-1}\right)$ & $1340^{\mathrm{b}} \pm 34.11$ & $1076^{\mathrm{a}} \pm 20.31$ & $1712^{\mathrm{b}} \pm 42.76$ \\
\hline
\end{tabular}


when Chilean jack mackerel was stored under oregano and rosemary extracts whereas Bensid et al. (2014) reported that the $\mathrm{pH}$ of anchovy was not significantly affected by icing with extracts from thyme, oregano and clove. The higher $\mathrm{pH}$ observed in fishes stored under conventional icing conditions during extended storage may be due to the generation of more bases associated with the degradation of tissue constituents.

\section{TVB-N}

The chemical spoilage of fish samples during storage is usually evaluated by measuring the changes in the content of TVB-N which mainly comprises ammonia and primary, secondary and tertiary amines produced as a result of microbial activity. The TVB-N of fresh fish was $13.2 \mathrm{mg} \%$. TVB-N slightly increased till $7^{\text {th }}$ and $10^{\text {th }}$ day of storage, respectively for samples stored under conventional ice and extracts incorporated ice. Thereafter, a marked increase was observed in all samples with the progress of storage period in ice (Fig. 2a). For samples under conventional ice, the TVB-N formation reached up to a level of $27.1 \mathrm{mg} \%$ on the sensory rejection day $\left(15^{\text {th }}\right.$ day). The development of TVB-N was significantly higher in conventional iced groups than that in $\mathrm{CE}$ and $\mathrm{ME}$ iced groups $(\mathrm{p}<0.05)$.

Concentration of TVB-N in freshly caught fish is typically between 5 and $20 \mathrm{mg} \mathrm{N} 100 \mathrm{~g}^{-1}$, whereas levels of $30-35 \mathrm{mgN} 100 \mathrm{~g}^{-1}$ fish are generally regarded as the limit of acceptability for ice-stored cold water fish (Connell, 1995). In our study, even though TVB-N showed an increasing trend, none of the samples crossed the established acceptable limit. Lower levels of TVB-N in extract iced samples can be attributed to its lower microbial counts compared to conventionally iced samples which further indicate the antibacterial effects of the extracts tested. An inhibitory effect by the presence of plant extracts in ice on TVB-N generation has been reported previously by Quitral et al. (2009) and Bensid et al. (2014).

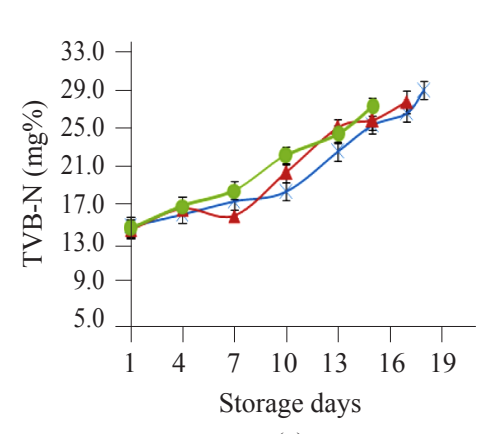

(a)

Fig. 2. Effect of different icing systems on (a

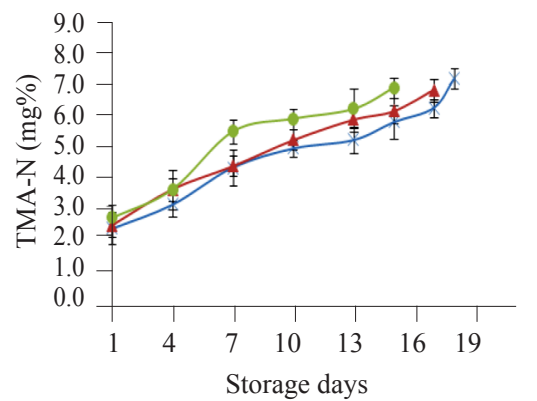

(b)

\section{TMA-N}

TMA-N is derived from trimethylamineoxide (TMAO) during spoilage in marine fishes. At the beginning of the storage, TMA-N values were determined as 2.1 mg100 $\mathrm{g}^{-1}$ flesh which increased significantly $(\mathrm{p}<0.05)$ with time of storage in all groups (Fig. 2b). After $4^{\text {th }}$ day of storage, samples stored in conventional ice indicated significantly higher $(\mathrm{p}<0.05)$ amounts of TMA-N than the samples stored under extract ices. Among the extract ices, mint extract ice significantly $(\mathrm{p}<0.05)$ reduced TMA-N formation on most of the sampling days. Presence of extract in ice might have reduced the activity of bacteria causing reduction of TMA-O to TMA-N, leading to significantly lower amounts of TMA-N in the treated samples.

Assessment of TMA-N in the present study did not provide a good indication of spoilage, as the evolution of TMA-N was quite low throughout the storage period. It has been reported that the level of TMA-N in numerous fatty fish never reached $5 \mathrm{mg} \%$ although the limit is $10-15$ mg\% (Sikorski et al., 1990; Ozogul et al., 2004). Although TMA-N is believed to be generated by the action of spoilage bacteria, the correlation with bacterial numbers is often not very good (Huss, 1995). Similarly, in this study, changes in the concentrations of TMA-N in mackerel during chilled storage did not correlate well with APC.

\section{NPN content}

Variations in the NPN content of all the samples are presented in Fig. 2c. A statistically significant reduction $(p<0.05)$ in NPN content with storage period was observed in the samples stored under conventional as well as extract icing systems. The rate of reduction was lower in fishes under ME ice compared to all other samples. With slight fluctuations, NPN content reduced from an initial value of $512 \mathrm{mg} \%$ in fresh mackerel to a final value of 478.67 , 436.0 and $474.18 \mathrm{mg} \%$ in samples stored under ME ice,

$$
* \mathrm{ME} \text { ice, } \rightarrow \mathrm{CE} \text { ice, } \rightarrow \mathrm{C} \text { ice }
$$

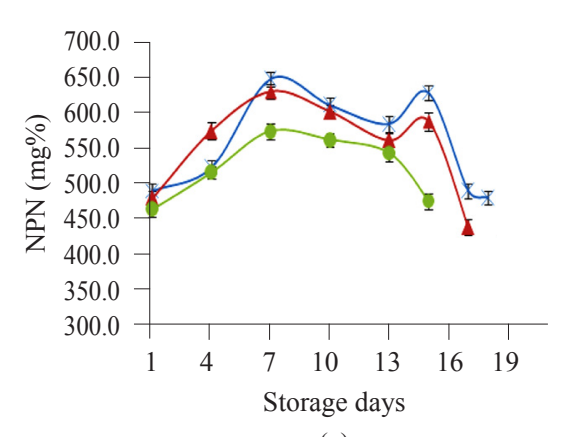

(c)

Fig. 2. Effect of different icing systems on (a) TVB-N, (b) TMA-N and (c) NPN of Indian mackerel during storage ( $\mathrm{n}=3$, mean \pm SD) 
CE ice and conventional ice, respectively on their final day of storage. As most of the non-protein nitrogen in fish is water soluble sarcoplasmic fractions, leaching out of these fractions into the melting ice is responsible for reduction in NPN content during storage. Meanwhile, the degradation of proteinaceous matter and free aminoacids by bacteria can make a rise in NPN content. Lapa Guimaraeus et al. (2005) reported a reduction in NPN content when squid is stored under ice. Leaching out of NPN compounds is also observed by Vaz-pirez et al. (2008) during the iced storage of cuttlefish and shortfin squid. The reduction in NPN content during storage can also be associated with the degradation of the low molecular weight amino acids or nucleotides by microorganisms. Accordingly, the rate of reduction was lower in samples kept under mint extract and citrus extract ice compared to conventional icing system.

FFA

The FFA values of fish muscle gives an account of the degree of lipid hydrolysis during spoilage. Initial FFA values of fish samples were found to be 0.948 (oleic acid \%). There was a marked increase in FFA content of all groups during storage (Fig. 3a). The FFA content increased from an initial value of $1.41,1.48$ and 1.74 to a final value of $7.15,6.81$ and $6.64 \%$ oleic acid in mackerel stored under $\mathrm{ME}$ ice, $\mathrm{CE}$ ice and conventional ice, respectively. On and after 7 days of storage, the FFA content of samples in conventional ice was significantly higher $(p<0.05)$ than that of samples stored under ME ice. Samples of CE iced group retained significantly $(\mathrm{p}<0.05)$ lower FFA content than that of $\mathrm{C}$ iced samples on $4^{\text {th }}, 10^{\text {th }}$ and $13^{\text {th }}$ day of storage. The lower FFA values in extract iced samples could be attributed to the effect of phenolic compounds of plant extracts which may suppress lipolytic bacteria responsible for liberating free fatty acids. Mint extract was found superior to citrus peel extract for controlling FFA formation.

\section{Peroxide value}

Shelf life of oily fish species is limited due to the oxidation of lipid. The primary product of lipid oxidation is fatty acid hydroperoxide, measured as PV. In this study, PV was employed for determining the amount of primary oxidation products during the storage period under different icing systems. Initial PV of fresh mackerel used in this study was determined as 3.29 meq $\mathrm{O}_{2} \mathrm{~kg}^{-1}$ of fat. The PV showed an increase in all groups $(\mathrm{p}<0.05)$ till a particular day of storage and thereafter, the values indicated a declining trend (Fig. 3b). This index exhibited a marked increase in the samples of conventional ice, in contrast to fishes kept under $\mathrm{ME}$ ice and $\mathrm{CE}$ ice conditions. The maximum PV recorded was $13.83 \mathrm{meq}$ $\mathrm{O}_{2} \mathrm{~kg}^{-1}$ of fat for samples under conventional ice on $13^{\text {th }}$ day and 10.05 and 12.36 meq $\mathrm{O}_{2} \mathrm{~kg}^{-1}$ of fat for samples stored in ME ice and $\mathrm{CE}$ ice, respectively on $15^{\text {th }}$ day of storage. It is inferred from the results that the presence of both extracts in the chilling medium led to a significant inhibition of peroxide formation. Mint extract showed the highest antioxidant effect in agreement with its in vitro antioxidant activities in whole mackerel compared to citrus peel extract and yielded lower peroxide generation during storage. Since, the fishes were in direct contact with extract ice, the phenolics present in ice might have reduced the hydroperoxide formation through scavenging the reactive fatty acid free radicals, thereby breaking the chain reaction of lipid oxidation. Similar findings were obtained for icing with rosemary extracts during the storage of Chilean jack mackerel (Quitral et al., 2009) and for icing with extracts from thyme, oregano and rosemary during storage of anchovy (Bensid et al., 2014). The reduction in PV in all the samples towards the end of storage period may be related to the secondary reactions of the hydroperoxides and volatilisation (Vidya and Srikar, 1996).

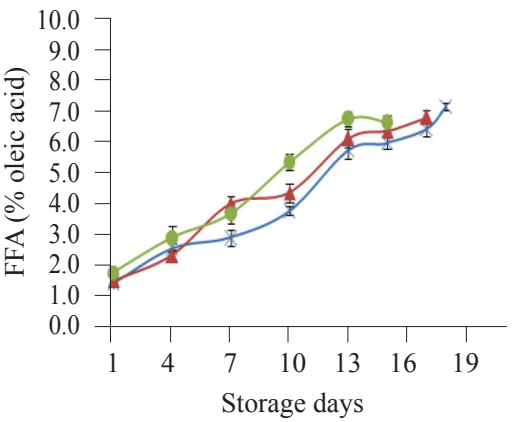

(a)

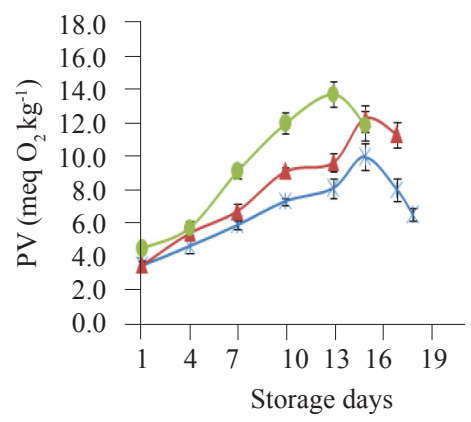

(b)

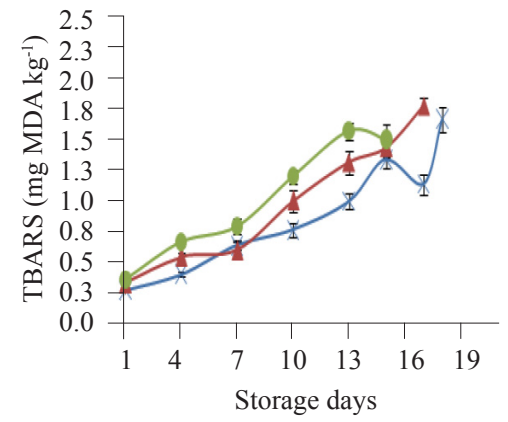

(c)

$* \mathrm{ME}$ ice, $\rightarrow \mathrm{CE}$ ice, $\rightarrow \mathrm{C}$ ice

Fig. 3. Effect of different icing systems on (a) FFA, (b) PV and (c) TBARS of Indian mackerel during storage ( $\mathrm{n}=3$, Mean \pm SD) 


\section{TBARS}

TBARS gives a measure of malonaldehyde (MDA), which is produced through secondary lipid oxidation from the degradation of hydroperoxides. As evident from Fig. 3c, a significant increase in TBARS was observed with storage time in ice, in all sample groups. On and after $3^{\text {rd }}$ day, higher TBARs value $(\mathrm{p}<0.05)$ in the conventional iced samples was observed in comparison to mackerel stored in ice with mint extract. Except for the $1^{\text {st }}, 4^{\text {th }}$ and $15^{\text {th }}$ day, the samples stored in ice with citrus peel extract also had significantly lower TBARS $(p<0.05)$ than that stored in conventional ice. On the final sampling day, the TBARS reached up to $1.586,1.683$ and $1.43 \mathrm{mg} \mathrm{MDA} \mathrm{kg}{ }^{-1}$ fish, respectively for samples in $\mathrm{ME}$ ice, CE ice and C ice. Nunes et al. (1992) reported that the acceptability limits of TBARS value for fish stored in ice were 5 - $8 \mathrm{mg} \mathrm{MDA} \mathrm{kg}^{-1}$ flesh. However, none of the samples crossed this limit during the entire storage period.

It was interesting to note that, although the samples showed comparatively higher PV, the TBARS values were comparatively lower. This could be probably due to a lower rate of degradation of peroxides formed during primary oxidation. In addition, the MDA can interact with nucleic acids, proteins, amino acids and phospholipids resulting in lower amounts of free MDA that can be detected by TBARS test (Pezeshk et al., 2011). Hence, TBARS index may not always give the actual level of lipid oxidation occurred. However, as observed from the present results, addition of extracts, especially mint extract in ice significantly inhibited secondary lipid oxidation in mackerel. These results are in agreement with those of Quitral et al. (2009), who reported that icing system with oregano and rosemary extracts generally showed lower TBARS value for jack mackerel (Trachurus murphyi). Similarly, Ozyurt et al. (2012) also found that icing with rosemary extract was effective in controlling TBARS values in sardine. Among the two extracts, mint extract was more effective in controlling secondary lipid oxidation than citrus peel extract, which may be attributed to the higher antioxidant activities of the former.

\section{$A P C$}

Aerobic plate count (APC) reflects the microbial quality of food and is useful for indicating potential spoilage of perishable products. The initial population of viable bacteria in fish used in this study was $4.94 \log \mathrm{cfu}^{-1}$. Bacteria grew significantly in all samples with progress of storage in ice (Fig. 4). APC of the samples under different conditions were comparable till 4 days of storage. On and after $7^{\text {th }}$ day of storage, the fishes stored in conventional ice showed significantly $(\mathrm{p}<0.05)$ higher levels of viable counts than their counterparts

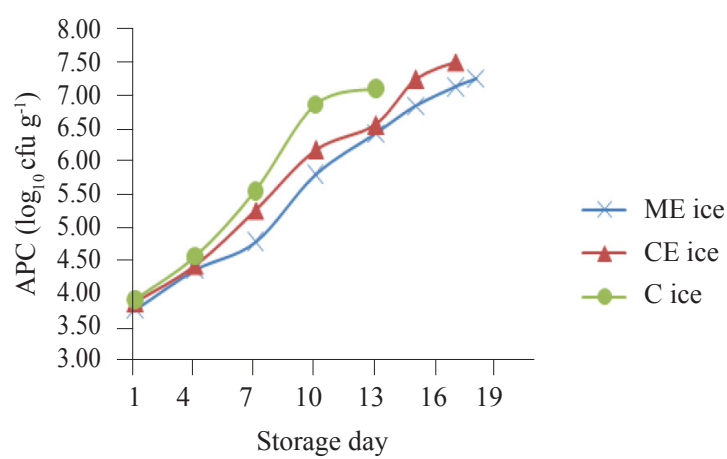

Fig. 4. Effect of different icing systems on APC of Indian mackerel during storage

stored in extract ices. In general, the counts of viable bacteria in conventional iced samples were ca. $0.5-1.0$ log cycles higher than those for the extract iced fishes after 1 week storage. The upper acceptable limit (M) for marine and freshwater fish proposed by ICMSF (1998) is $7 \log _{10} \mathrm{cfu} \mathrm{g}^{-1}$ and it has been considered as the standard for establishing microbial limits in fresh fish by many researchers (Pezeshk et al., 2011; Houicher et al., 2013). Fishes stored in conventional ice, citrus peel extract ice and mint extract ice crossed this limit on $13^{\text {th }}, 15^{\text {th }}$ and $17^{\text {th }}$ day of storage, respectively.

The results revealed that microbiological growth was significantly influenced by the addition of plant extract in ice. In ME and CE iced fishes, even though microbiological limit was crossed before the end of their storage life, it was not reflected on sensory analysis. This may probably be due to reduced spoilage activities of the bacteria in presence of extracts in the chilling medium. Accordingly, the fishes were not rejected by the sensory panellist on the day when the samples crossed the microbiological limit. Similar findings were earlier reported by Viji et al. (2015) in gutted sutchi catfish during ice storage.

The analysis indicated that mint extract with effective antimicrobial activities, could significantly delay microbial growth and extend the shelf life by 4 days. Work done by Sugandhi and Meera Bai (2011) showed that the ethanol extract of $M$. arvensis inhibited the growth of Escherichia coli, Pseudomonas aeruginosa, Shigella flexineri, Klebsiella pneumoniae and Staphylococcus aureus in vitro. Hence, the mint extract with effective antimicrobial and antioxidant activities, could significantly delay microbial growth and lipid oxidation and can act as a natural food preservative in ice. Similar to this finding, presence of thyme in ice extended the microbiological shelf life of anchovies by 3 days compared to conventional ice (Bensid et al., 2014). However, so far no studies reported regarding the effect of icing with mint and citrus peel extracts on microbiological quality of fish. 


\section{Sensory evaluation}

Changes in the overall acceptability scores over the storage period are presented in the Fig. 5. Sensory scores of fishes in conventional and extracts ice declined with the progress of ice storage. Sensory deterioration was faster in conventional iced groups followed by $\mathrm{CE}$ iced groups than their counterparts in ME group. Even though the samples of ME group had higher overall acceptability score, the colour and appearance of raw pieces scored lower towards the end of storage life. However, it was not observed in cooked pieces, which could be due to leaching of mint flavour during boiling. Progress of fish spoilage in the whole fish was evident by development of putrid odours, slimy and soft flesh. The samples were considered unfit for consumption when the overall score crossed 4. Accordingly, the panellists rejected the $\mathrm{C}$, $\mathrm{CE}$ and ME group on $15^{\text {th }}, 17^{\text {th }}$ and $18^{\text {th }}$ day of storage, respectively. Hence, taking into account microbiological and sensory analysis, the shelf life was determined to be 13 days for mackerel stored in conventional ice and 15 days and 17 days for fishes stored in citrus peel extract ice and mint extract ice, respectively. Ozyurt et al, (2012) studied shelf life of sardine (Sardinella aurita) stored in ice with rosemary and their results showed that the addition of natural extract improved the sensory quality of fish and extended the shelf life by 3 days compared with the control samples.

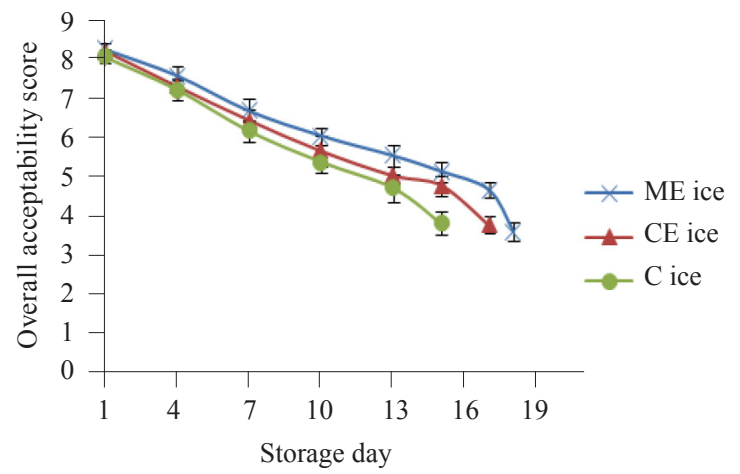

Fig. 5. Effect of different icing systems on the sensory score of Indian mackerel during storage $(n=5$, mean $\pm \mathrm{SD})$

The preservative effects displayed by plant extracts incorporated ice could be attributed to the presence of bioactive phytochemicals in the extracts. The major phenolics reported in mint leaves are rosemarinic acid, caffeic acid, eriocitrin and luteolin (Padmini et al., 2010; Kappa et al., 2013) with potential antibacterial and antioxidant activities (Singh et al., 2010). Manthey and Grohmann (2001) reported that polyphenol compounds such as $p$-coumaric, ferulic and sinapic acids and narirutin are present in citrus peel extract. Constituents such as gamma-terpinene, terpinolene, alpha-terpinene, hesperidin and neohesperidin are also found to be responsible for the preservative action in citrus species (Singh et al., 2010).

The present study clearly indicates the potential use of a novel icing system incorporated with extracts from mint leaf and citrus peel in chilled storage of fish. Presence of extracts, especially mint extract significantly delayed the biochemical, microbiological and sensory quality changes and extended the shelf life of Indian mackerel by 5 days. The antioxidant effects of extracts were extremely prominent from the significantly lower values of lipid oxidation indices like PV and TBARS in the treated groups. Also, the presence of extracts in ice significantly $(p<0.05)$ suppressed the growth of bacteria as determined by the counts of total viable bacteria. Findings of the present work are noteworthy as the shelf life of Indian mackerel is often limited due to lipid oxidation and rancidity. It can be concluded that modification of icing medium by incorporating natural plant extracts can be useful for the food industry to extent the shelf life during storage and distribution.

\section{Acknowledgements}

The authors thank the Indian Council of Agricultural Research, New Delhi for the financial support. We also thank, Mrs. Priyanka Vichare for her sincere assistance in carrying out the analyses.

\section{References}

Alongo, M. L., Alvarez, A. I. and Zapico, J. 1994. Rapid analysis of free aminoacids in infant food. J. Liquid Chromatograph., 17: 19-40.

Amerine, M. A., Pongborn, R. H. and Roescler, E. B. 1965. Principles of sensory evaluation of food. Academic Press, New York, 602 pp.

AOAC 1989. Official methods and recommended practices of American Oil Chemists Society, $5^{\text {th }}$ edn. Association of Official Analytical Chemists, Champaign, USA.

AOAC 1998. Official methods of analysis. $17^{\text {th }}$ edn. Association of Official Analytical Chemists, Washington DC, USA

Asjad, H. M. M., Akhtar, M. S., Bashir, S. Din, B., Gulzar, F., Khalid, R. and Muhammad Asad, M. 2013. Phenol, flavonoid contents and antioxidant activity of six common citrus plants in Pakistan. J. Pharma. Cos. Sci., 1: 1-5.

Babbar, N., Oberoi, H. S., Uppal, S. and Patil, R. T. 2011. Total phenolic content and antioxidant capacity of extracts obtained from six important fruit residues. Food Res. Int., 44: 391-396.

Bensid, A., Ucar, Y., Bendeddouche, B. and Ozogul, F. 2014. Effect of the icing with thyme, oregano and clove extracts on quality parameters of gutted and beheaded anchovy (Engraulis encrasicholus) during chilled storage. Food Chem., 145: 681-686. 
Benzie, I. F. F. and Strain, J. J., 1996. The ferric reducing ability of plasma (FRAP) as a measure of "antioxidant power": The FRAP assay. Anal. Biochem., 239: 70-76.

Connell J. J. 1995. Control of fish quality, Fishing New Books. Blackwell Science Ltd., Cambridge, London, 241 pp.

Conway, E. J. 1950. Micro-diffusion analysis and volumetric error. Lockwood and Son Ltd., Crosby, London.

Duh, P. D. 1998. Antioxidant activity of Budrock (Arctium lappa Linn): its scavenging effect on free radical and active oxygen. J. Am. Oil Chem. Soc., 75: 455-461.

Garcia-Soto, B., Aubourg, S. P., Calo-Mata, P. and BarrosVelazquez. J. 2013. Extension of the shelf life of chilled hake (Merluccius merluccius) by a novel icing medium containing natural organic acids. Food Cont., 34: 356-363.

Ghasemia, K., Ghasemia, Y. and Ebrahimzadeh, M. A. 2009. Antioxidant activity, phenol and flavonoid contents of 13 citrus species peels and tissues. Pak. J. Pharma. Sci., 22: $277-281$.

Houicher, A., Kuley, E., Bendeddouche, B., Ozogul, F. 2013. Effect of Mentha spicata L. and Artemisia campestris extracts on the shelf life and quality of vacuum packed refrigerated sardine (Sarda pilchardus) fillets. J. Food Protect., 76: 1719-1725.

Huss, H. H. 1995. Quality and quality changes in fresh fish. FAO fisheries technical paper, 348 pp.

ICMSF 1998. Microorganisms in foods. International Commission on Microbiological Specifications for Foods. Microbial Ecology of Food Commodities, Blackie Academic and Professional, Baltimore.

Janifer Raj, X., Bajpai, P. K., Phani Kumar, G., Pal Murugan, M., Kumar, J., Chaurasia, O. P. and Singh, S. B. 2010. Determination of total phenols, free radical scavenging and antibacterial activities of Mentha longifolia Linn. Hudson from the Cold Desert, Ladakh, India. Phcog J., 2: 470-475.

Jeong, S. M., Kim, S. Y., Kim, D. R., Jo, S. C., Nam, K. C. and Ahn, D. U. 2004. Effect of heat treatment on antioxidant activity of citrus peels. J. Agr. Food Chem., 52: 3389-3393.

Kannatt, S. R., Chander, R. and Sharma, A. 2008. Chitosan and mint mixture: a new preservative for meat and meat products. Food Chem., 107: 845-852.

Kappa, K., Hakala, E., Orav, A., Pohjala, A., Vuorela, P., Pussa, T., Vuorela, H. and Raal, A. 2013. Commercial peppermint (Mentha piperita L.) teas: Antichlamydial effects and polyphenolic composition. Food Res. Int., 53: 758-766.

Lapa-Guimaraes, J., Felıcio, P. E. de and Contreras, E. S. G. 2005. Chemical and microbial analyses of squid muscle (Loligo plei) during storage in ice. Food Chem., 91: 477-483.

Manthey, J. A. and Grohmann, K. 2001. Phenols in citrus peel byproducts. Concentrations of hydroxycinnamates and polymethoxylated flavones in citrus peel molasses. J. Agr. Food Chem., 49: 3262-3273.
Moreira, M. R., Ponce, A. G., Del-Valle, C. E. and Roura, S. I. 2005. Inhibitory parameters of essential oils to reduce a food borne pathogen. Lebensmittel., 38: 565-570.

Nunes, M. L., Cardinal, M., Mendes, R., Morao Campos, R., Bandarra, N. M. and Lourenco, H. 1992. Effect of season and storage on proteins and lipids of sardine (Sardine pilchardus) minces and surimi. In: Huss, H. H., Jakobsen, M. and Liston, L. (Eds.), Quality assurance in the fish industry. Amsterdam: Elsevier, p. 73-81.

Oral, N., Gulmez, M., Vatansever, L. and Guven, A. 2008. Application of antimicrobial ice for extending shelf life of fish. J. Food Prot., 71: 218-222.

Ordonez, A. A. L., Gomez, J. D., Vattuone, M. A. and Isla, M. I. 2006. Antioxidant activities of Sechium edule (Jacq). Food Chem., 97: 452-458

Ozogul, F., Polat, A. and Ozogul, Y. 2004. The effects of modified atmosphere packaging and vacuum packaging on chemical, sensory and microbiological changes of sardines (Sardina plichardus). J. Food Chem., 85: 49-57.

Ozyurt, G., Kuley, E., Balikei, E., Kacar, C., Gokogan, S., Etyemez, M. and Ozogul, F. 2012. Effect of icing with rosemary extract on the oxidative stability and biogenic amine formation in sardine (Sardinella aurita) during chilled storage. Food Biopro. Technol., 5: 2777-2786.

Padmini, E. A., Valaemathi, M. and Ran, U. 2010. Comparative analysis of chemical composition and antibacterial activities of Mentha spicata and Camella sinensis. Asian J. Exp. Biol., 4: 772-781.

Pezeshk, S., Rezaei, M., Hosseini, H. 2011. Effect of turmeric, shallot extracts and their combinations on quality characteristics of vacuum packaged rainbow trout stored at $4 \pm 1^{\circ}$ C. J. Food Sci., 76: 387-391.

Quitral, V., Donoso, M. L., Ortiz, J., Herrera, M. V., Araya, H. and Aubourg, S. P. 2009. Chemical changes during the chilled storage of Chilean jack mackerel (Trachurus murphyi): Effect of a plant-extract icing system. LWT Food Sci. Technol., 42: 1450-1454.

Ryser, E. T. and Schuman, J. 2013. Aerobic plate count, In: Compendium of method for the microbiological examination of foods. American Public Health Association, Washington, D.C, USA. doi: 10.2105/MBEF.0222.013.

Shan, B., Cai, Y. Z., Brooks, J. D. and Corke, H. 2007. The in vitro antibacterial activity of dietary spice and medicinal herb extracts. Int. J. Food Microbiol., 117: 112-119.

Shinde, P. A., Reddy, V. K. S. and Patange, S. B. 2015. Quality of Indian mackerel as affected by pomegranate peel and tea leaf extracts during ice storage. SAARC J. Agr., 13: 109-122.

Sikorski, Z. E., Kolakowska, K. and Burt, J. R. 1990 Post-harvest, biochemical and microbial changes. In: Sikorski, Z. E. (Ed.), Seafood: resources, nutritional 
composition, and preservation. CRC Press, Inc. Boca Raton, p. 55-75.

Singh, A., Sharma, P. K. and Garg, G. 2010. Natural products as preservatives. Int. J. Pharma. Biol. Sci., 1: 601-612.

Singleton, V. L. and Rossi, J. A. 1965. Colorimetry of total phenolics with phosphomolybdic phosphotungstic acid reagents. Am. J. Enol. Viticult.,16: 144-158.

Stanisavljevic, D. M., Stojicevic., S. S., Sofija, M., Zlatkovic, B. P., Velickovic, D. T. Karabegovic, I. T. and Lazic, M. L. 2012. Antioxidant activity, the content of total phenols and flavonoids in the ethanol extracts of Mentha longifolia (1.) Hudson, dried by the use of different techniques. Chemical Industry and Chemical Engineering Quarterly, 18: 411-420.

Sugandhi, B. R. M. and Meera Bai, G. 2011. Antimicrobial activity of Mentha Arvensis L. Lamiaceae. J. Adv. Lab. Res. Biol., 2: 8-11.

Tarladgis, B. G., Watts, B. M. and Younthan, M. T. 1960. A distillation method for the quantitative determination of malonaldehyde in rancid foods. J. Am. Oil Chem. Soc., 37: 44-48

Vaz-Pires, P., Seixas, P., Mota, M., Lapa-Guimarães, J., Pickova, J., Lindo A. and Silva, T. 2008. Sensory, microbiological, physical and chemical properties of cuttlefish (Sepia officinalis) and broadtail shortfin squid (Illex coindetii) stored in ice. LWT - Food Sci. Technol., 41: 1655-1664.

Vidya, S. R. and Srikar, L. 1996. Effect of pre-process ice storage on lipid change of Japanese threadfin bream (Nemipterus japonicus) mince during frozen storage. Asian Fish. Sci., 9: 109-114.

Viji, P., Binsi, P. K., Visnuvinayagam, S. and Srinivasa Gopal, T. K. 2015. Efficacy of Mint (Mentha arvensis) leaf and Citrus (Citrus aurantium) peel extracts as natural preservatives for shelf life extension of chill stored Indian mackerel. J. Food Sci. Technol., 52: 6278-6289.

Viji, P., George, N., Lalitha, K. V., Zynudheen, A. A., Tanuja, S., Binsi, P. K. and Srinivasagopal, T. K. 2015. Biochemical, textural, microbiological and sensory attributes of gutted and ungutted sutchi catfish (Pangasianodon hypophthalmus) stored in ice. J. Food Sci. Technol., 52: 3312-3321.

Wang, Y. C., Chuang, Y. C. and Hus, H. W. 2008. The flavonoid, carotenoid and pectin content in peels of citrus cultivated in Taiwan. Food Chem., 106: 277-284.

Yildiz, G., Wehling, R. and Cuppett, S. L. 2003. Comparison of four analytical methods for the determination of peroxide value in oxidized soybean oils. J. Am. Oil Chem. Soc., 80: 103-107.

Date of Receipt $\quad$ : 03.11.2015

Date of Acceptance : 10.05 .2016 